\title{
Antihypertensive effect of the mineralocorticoid receptor antagonist eplerenone: a pooled analysis of patient-level data from comparative trials using regulatory-approved doses
}

This article was published in the following Dove Press journal: Vascular Health and Risk Management

\author{
Mireille Fernet' \\ Bruce Beckerman ${ }^{2}$ \\ Paula Abreu² \\ Katharina Lins ${ }^{3}$ \\ John Vincent ${ }^{2}$ \\ Ellen Burgess ${ }^{4}$ \\ 'Department of Medical Affairs, \\ Pfizer Canada Inc., Kirkland, QC, \\ Canada; ${ }^{2}$ Department of Clinical \\ Affairs, Pfizer Inc., New York, NY, USA \\ ${ }^{3}$ Department of Medical Affairs, Pfizer \\ Ltd., Tadworth, UK; ${ }^{4}$ Department \\ of Medicine, Faculty of Medicine, \\ University of Calgary, Calgary, AB, \\ Canada
}

\begin{abstract}
Purpose: Several options are available for the treatment of hypertension; however, many treated patients are still not below blood pressure (BP) target. Eplerenone, a selective mineralocorticoid receptor antagonist, is an approved treatment option for the management of patients with hypertension in a number of countries. This patient-level pooled analysis was conducted to document the efficacy and safety/tolerability of eplerenone at the dosages approved for use in hypertension in comparison to placebo or other approved antihypertensive agents.
\end{abstract}

Methods: Seventeen Phase III studies conducted in patients with mild-to-moderate hypertension in the Eplerenone Hypertension Clinical Program were reviewed; eleven met the selection criteria. The primary endpoint was change from baseline in seated diastolic BP and seated systolic BP measured at the end of the study.

Results: A total of 2,698 patients were included in this per-protocol analysis. In patients treated for at least 6 weeks with a stable dose of eplerenone, doses of $50 \mathrm{mg}$ daily and $100 \mathrm{mg}$ daily were associated with greater reductions of seated systolic BP and seated diastolic BP compared with placebo $(P<0.001)$ and active-controlled studies $(P<0.033)$. In the analysis of covariance model testing of the contribution of four factors (age, body mass index [BMI], history of cardiovascular disease, and diabetes) on the BP lowering effects of eplerenone, only BMI and age were associated with small though statistically significant changes in $\mathrm{BP}(<0.2 \mathrm{mmHg})$. Eplerenone was well tolerated; headache was the most common adverse event for patients in any group. Severe hyperkalemia (serum potassium level $>6.0 \mathrm{mmol} / \mathrm{L}$ ) occurred in up to $0.4 \%$ in the eplerenone groups, $0.4 \%$ in the placebo group, and $0.1 \%$ in the active-control group.

Conclusion: This patient-level pooled analysis provides robust evidence that eplerenone, at 50 $\mathrm{mg}$ or $100 \mathrm{mg}$ daily, was effective in lowering BP in patients with mild-to-moderate hypertension and was well tolerated.

Keywords: hypertension, eplerenone, aldosterone, cardiovascular, selective mineralocorticoid blocker

\section{Introduction}

Hypertension is a significant risk factor for the progression of atherosclerosis and associated cardiovascular (CV) events such as stroke and myocardial infarction, as well as the development and progression of heart failure and renal disease. ${ }^{1}$ The treatment for hypertension has been demonstrated to reduce $\mathrm{CV}$ events, prevent premature deaths, and prolong life. ${ }^{2}$ The control rates for hypertension have improved in most countries over the past 20 years with the biggest difference in physician practice being the prescription
Correspondence: Ellen Burgess

Department of Medicine, Faculty of

Medicine, University of Calgary, I403-

29th Street, NW, Calgary, AB T2N2T9,

Canada

Tel +l 403944 I598

Fax + I 4039442876

Email ellen.burgess@ahs.ca 
of two or more antihypertensive medications rather than using fewer medications. ${ }^{3,4}$ However, approximately $35 \%-50 \%$ of patients remain above their target blood pressure (BP). ${ }^{3,5,6}$ Recently, trials have demonstrated the value of treating to lower target BPs (reduction in fatal and nonfatal major CV events and death from any cause for $\mathrm{SPRINT}^{7}$ and reduction in stroke for $\mathrm{ACCORD}^{8}$ ); attainment of these targets requires more drugs, and more patients will not reach these lower target BPs. Studies of patients with primary, secondary, or resistant hypertension have demonstrated the role of aldosterone and the effect of mineralocorticoid receptor antagonists (MRAs) in lowering BP in those patients. ${ }^{9-12}$

Aldosterone has been described as having an important influence on $\mathrm{CV}$ and renal diseases through the elevation of systemic BP as well as the development of fibrosis in the vasculature. The use of angiotensin converting enzyme inhibitors (ACEIs) and angiotensin II type 1-receptor blockers (A-II antagonist) was initially shown to reduce plasma levels of aldosterone, but after 6-12 months of therapy, plasma aldosterone levels have been demonstrated to rise back to baseline levels (a phenomenon termed "aldosterone breakthrough"). ${ }^{13}$ The use of the MRAs, spironolactone and eplerenone, has been formally documented to be effective in reducing mortality in patients with chronic systolic heart failure, including patients with mild ${ }^{14}$-to-severe ${ }^{15}$ heart failure symptoms, as well as in patients with signs and symptoms of heart failure post myocardial infarction, ${ }^{16}$ when added to the standard of care including ACE-I or A-II antagonist and beta-blocker therapy. Both spironolactone and eplerenone have also been found to be effective in reducing BP in patients with hypertension. ${ }^{17,18}$ Eplerenone was first approved for the treatment of hypertension in 2002 in the United States. It then received the indication of systolic heart failure post myocardial infarction in the USA, Europe, and eventually Canada; eplerenone was approved for chronic systolic heart failure in 2012 in Canada, Europe, and elsewhere. In Canada, the regulatory indication for use in mild and moderate essential hypertension was granted in 2014. Canada is one of seven countries in which eplerenone has an indication for the treatment of hypertension.

Eplerenone is referred to as a selective MRA since it is much more selective in binding to the mineralocorticoid receptor than spironolactone, with minimal binding to glucocorticoid, progesterone, and androgen receptors. ${ }^{19-22}$ Consequently, the likelihood of adverse effects such as gynecomastia, reduced libido, metabolic adverse effects (eg, increased A1c and cortisol), and menstrual irregularities is decreased. ${ }^{23,24}$ Furthermore, this selectivity might have additional clinical implications since the long-term effects of androgen inhibition (reduced levels of anabolic hormones such as testosterone and dehydroepiandrosterone sulfate) have been documented to constitute strong markers of poor prognosis independent of conventional risk predictors in men with chronic heart failure. ${ }^{25}$

The efficacy of eplerenone in hypertension has been evaluated in several studies, using doses ranging from 25 to $400 \mathrm{mg}$ daily. The objective of this analysis was to pool patient-level data from the Eplerenone Hypertension Clinical Program, in which patients received eplerenone at the approved dosage for hypertension of $50 \mathrm{mg}$ daily or $100 \mathrm{mg}$ daily, ${ }^{26}$ for the purpose of documenting the efficacy and safety of this treatment, in comparison to placebo or other approved antihypertensive agents.

\section{Patients and methods}

\section{Selection criteria - studies and patients}

Seventeen Phase III studies were conducted in the Eplerenone Hypertension Clinical Program sponsored by the originator pharmaceutical company and reviewed; eleven studies met inclusion criteria and were analyzed. Of the remaining six studies, four were conducted in a patient population outside the approved indication and two studies were not controlled clinical trials and therefore were excluded from this analysis (see Supplementary materials for more details regarding each study). The study selection was based on the following criteria:

- Phase III, randomized, placebo-controlled and activecontrolled, parallel-group studies conducted as part of the Eplerenone Hypertension Clinical Program

- Approved doses of eplerenone for the treatment of hypertension are 50 and $100 \mathrm{mg}$ daily. These included $25 \mathrm{mg}$ BID, $50 \mathrm{mg}$ QD, $50 \mathrm{mg}$ BID, and $100 \mathrm{mg}$ QD. All other arms used daily doses of $<50 \mathrm{mg}$ daily or $>100 \mathrm{mg}$ daily, which are not approved for the hypertension indication and were thus excluded from this analysis

- Individual clinical subject-level data were available

There were two categories of study: category 1: placebocontrolled, fixed-dose studies (study numbers 010, 015, 049, and 403) or titrate-to-effect studies (study numbers 020,023 , and 024$)$ and category 2 : active-controlled, fixed-dose studies (study numbers 010 and 015 ) or titrate-to-effect studies (study numbers 016, 019, 020, 022, and 026). Some trials used both placebo and active comparators and were included in the analysis of both categories 1 and 2. Eplerenone was compared in seven trials with placebo and in seven trials with active comparators (three trials were both placebo and 
active controlled). Eplerenone was coadministered with other antihypertensive medication (hydrochlorothiazide, a calcium channel blocker, a beta-blocker, an ACE-I or an A-II antagonist) in three of the eleven studies included in the pooled analysis. Study durations varied from 8 to 24 weeks (see Supplementary materials for study references).

\section{Study population from selected studies}

Patients with mild-to-moderate hypertension were eligible to participate in the eplerenone Phase III hypertension studies if they met the entry criteria. To qualify for inclusion, participants from ten of the eleven selected studies must have been adults with a history of mild-to-moderate hypertension currently controlled with medication or, if untreated, mildto-moderate hypertension. To qualify for admission in the eleventh study included in this pooled analysis, participants must have been $\geq 50$ years of age with elevated systolic BP (SBP; see Supplementary materials for individual study key inclusion criteria).

\section{Outcome measures - endpoints}

The primary endpoint was defined as the change from baseline in seated diastolic BP (seDBP) and seated systolic BP (seSBP) captured at the end of the study. The proportion of patients who achieved BP targets of seSBP and seDBP 140/90 $\mathrm{mmHg}$ was computed as a secondary endpoint.

Safety data (adverse events [AEs] and serious AEs [SAEs]) were summarized as well as discontinuations due to AEs. Clinical laboratory data analyzed included change from baseline in serum potassium levels (mean \pm SD) at final visit, and the number of subjects reaching specific serum potassium levels, as well as incidence of hyperkalemia and hypokalemia reported as AEs by the investigators.

Two analyses sets were considered: the efficacy "perprotocol" and the safety analysis set. The efficacy "perprotocol" analysis set included all subjects

- who were randomly assigned to treatment

- who had a baseline and post-baseline primary efficacy evaluation

- who received at least 6 weeks of fixed dose of study drug.

The safety analysis set included all subjects

- who were randomly assigned to treatment

- who took at least one dose of double-blind study drug.

\section{Statistical analysis}

Patient-level data were utilized in all analyses. The demographics and the efficacy analyses were performed on the "per-protocol" population noted above. The safety analysis was performed on the safety population. The pooled analysis inclusion criteria for studies and populations were prespecified prior to analysis being performed. Additionally, the clinical trial selection criteria, key efficacy, and safety endpoints and the statistical methods were prespecified prior to performing any analysis.

Patient disposition by study and pooled categories of studies were summarized by dose ( $50 \mathrm{mg}$ daily/100 mg daily) and placebo/active controls dependent on the pooled analysis. Patient disposition described the number of subjects randomized and subjects with baseline and post baseline assessment. Demographics, baseline characteristics, and duration of treatment were summarized by treatment. Descriptive statistics such as observed raw means and standard deviations, and change from baseline to end-of-treatment (the only exception being study 016, as explained in the Supplementary materials), were calculated by treatment group for each study. Differences in adjusted means between each treatment group and the placebo or active control comparator and their respective $95 \%$ confidence intervals were presented. An analysis of covariance (ANCOVA) with treatment group as the factor and baseline value as a covariate was used to analyze between group differences for the mean change in seDBP and seSBP from baseline. The percentage of patients within each group reaching target BP was calculated as a secondary efficacy outcome, using descriptive statistics.

The goal was not to provide inferential analyses but to summarize the available data. Results were incorporated into two pooled analyses: a placebo-controlled pooled analysis and an active-controlled pooled analysis. A fixedeffects model was used for both pooled analyses. Change from baseline in seSBP and seDBP was analyzed using an ANCOVA model with treatment, study, and baseline covariate (seSBP and seDBP) in the model. For all efficacy endpoints, the analyses were performed at the end of study and for the above-described efficacy population. The overall estimate of treatment difference of each group vs placebo and vs active comparator, standard error, and associated $95 \% \mathrm{CI}$, as well as overall $P$-value are provided. Forest plots were produced to illustrate the results of each pooled analysis, as well as summarizing estimates for the difference in least-square (LS) means and 95\% CIs.

\section{Subgroup analysis}

In this pooled analysis, the effects of baseline characteristics of the hypertensive patients on the BP response were explored. Subgroup analyses were performed for the primary 
efficacy endpoint for the following baseline characteristics: age at entry (<64 years, $\geq 64$ years), BMI $\left(>30 \mathrm{~kg} / \mathrm{m}^{2} / \leq 30\right.$ $\mathrm{kg} / \mathrm{m}^{2}$ ); history of CV disease (yes, no), and diabetes mellitus (yes, no). Both history of CV disease and diabetes mellitus were based on the investigator's assessment of medical history documentation. The association between the BP measurements and the identified risk factors listed above were described using differences in LS means and $P$-values from an ANCOVA model with terms for treatment and study.

\section{Ethical approval}

This article contains results of secondary analysis of studies with human participants previously performed.

\section{Results}

\section{Patient disposition}

The per-protocol analysis set included 2,698 patients; of these, 1,394 were from placebo-controlled studies and 1,304 from active-controlled studies. The safety analysis set included 3,192 patients; of these, 1,677 were from placebocontrolled studies and 1,515 from active-controlled studies (Table 1). The following antihypertensive medications were included in the active-controlled studies; spironolactone 50 $\mathrm{mg}$ BID, hydrochlorothiazide $12.5 \mathrm{mg}$ QD and $25 \mathrm{mg}$ QD, losartan $50 \mathrm{mg}$ QD and $100 \mathrm{mg}$ QD, enalapril $5 \mathrm{mg}$ QD, 10mg QD, $20 \mathrm{mg}$ QD, and $40 \mathrm{mg}$ QD, amlodipine $2.5 \mathrm{mg}$ QD, $5 \mathrm{mg}$ QD, and $10 \mathrm{mg}$ QD (see Supplementary materials for more details on individual studies).

Reasons for lack of eligibility for the pooled analysis are presented in Figure 1A, B for the placebo-controlled and active-controlled studies, respectively.

Baseline characteristics of the patients were similar among the treatment groups. Table 2 summarizes key demographic values and clinical characteristics. Patients enrolled in active-controlled studies tended to have a higher rate of CV disease.

\section{Efficacy findings}

Eplerenone was compared in seven trials to placebo and in seven trials to active comparators. The primary endpoint was defined as the change from baseline of seDBP and seSBP captured at the end of the study. In order to account for heterogeneity in different studies, an ANCOVA was conducted; the LS means and $P$-values are summarized in Tables 3 and 4. In patients with mild-to-moderate primary hypertension treated for at least 6 weeks on a stable dose, both eplerenone $50 \mathrm{mg}$ daily and $100 \mathrm{mg}$ daily reduced seSBP and seDBP from baseline (Table 3A, B). Compared with placebo and active controlled, the changes from baseline in seSBP/seDBP were statistically significantly greater $(P$-value $<0.001$ and $P$-value $<0.033$, respectively) with eplerenone. Descriptive statistics are summarized in the Supplementary materials.

Forest plots of the fixed-effects model for the pooled analysis including estimates and 95\% confidence intervals of the mean changes from baseline in seSBP and seDBP are presented in Figure 2A for eplerenone $50 \mathrm{mg}$ daily and 100 $\mathrm{mg}$ daily vs placebo, and Figure $2 \mathrm{~B}$ for eplerenone $50 \mathrm{mg}$ daily and $100 \mathrm{mg}$ daily vs active control.

The proportion of patients reaching BP treatment goal ( $<140 / 90 \mathrm{mmHg}$ ) by the end of study were $31.4 \%, 45.4 \%$, and $35.8 \%$ respectively for placebo-, eplerenone $50 \mathrm{mg}$ - and eplerenone $100 \mathrm{mg}$-treated patients in the placebo-controlled studies. In the active-controlled studies, this proportion was $40.2 \%, 46.5 \%$, and $45.8 \%$ for active-controlled patients, eplerenone $50 \mathrm{mg}$ - and eplerenone $100 \mathrm{mg}$-treated patients, respectively.

\section{Subgroup analysis (Exploratory efficacy analyses)}

Changes from baseline in seSBP and seDBP were analyzed using an ANCOVA model that included preidentified factors of age group, BMI, history of CV disease, and diabetes mellitus as covariates. In this ANCOVA model, two factors of interest were associated with statistically significant changes from baseline in seSBP (BMI) and seDBP (age), that is, the model indicated that BMI had a statistically significant impact on seSBP, and age had a statistically significant impact on seDBP. While these factors resulted in statistical differences compared with the unadjusted analysis, the size of the differences was not considered clinically meaningful, that is,

Table I Overview of patient disposition

\begin{tabular}{lllll}
\hline Type of studies & $\begin{array}{l}\text { Patients } \\
\text { randomized }\end{array}$ & $\begin{array}{l}\text { Patients } \\
\text { treated }\end{array}$ & $\begin{array}{l}\text { Patients with post-baseline } \\
\text { efficacy assessments }\end{array}$ & $\begin{array}{l}\text { Patients receiving at least 6 weeks } \\
\text { of fixed dose of study drug }\end{array}$ \\
\hline Placebo-controlled studies & 1,679 & 1,677 & 1,640 & 1,394 \\
Active-controlled studies & 1,517 & 1,515 & 1,469 & 1,304 \\
Total & 3,196 & 3,192 & 3,109 & 2,698 \\
\hline
\end{tabular}

Notes: Placebo-controlled studies included 010, 015, 020, 023, 024, 049, and 403. Active-controlled studies included 010, $015,016,019,020,022$, and 026. 
A

Randomization

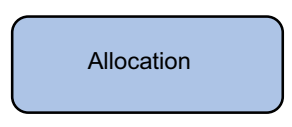

Patients not eligible for the pooled analysis

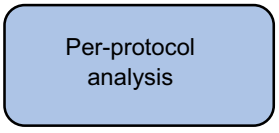

B
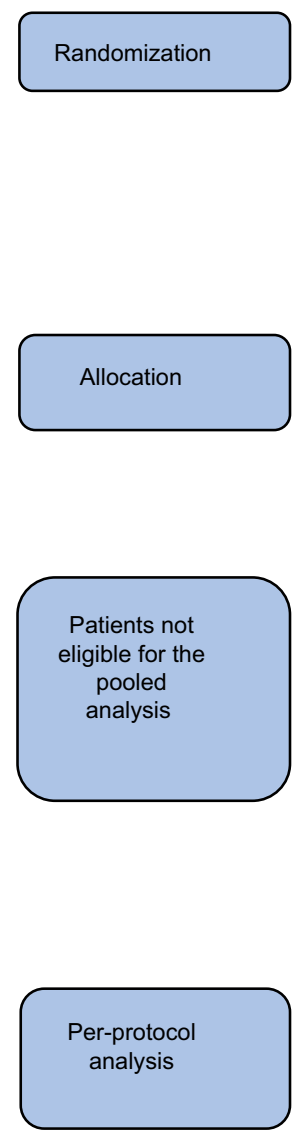
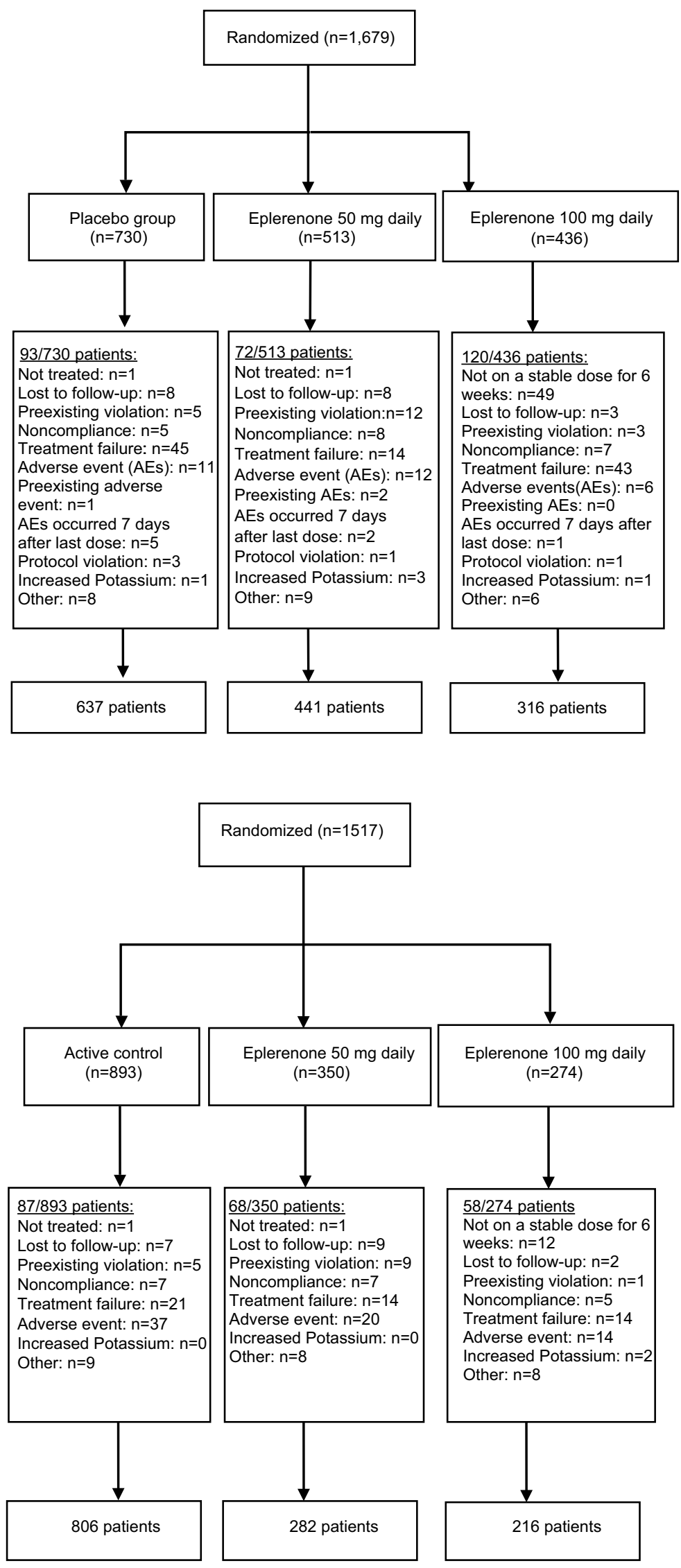

Figure I Patient disposition. (A) Placebo-controlled studies. (B) Active-controlled studies. 
Table 2 Baseline demographic and clinical characteristics of per-protocol set ${ }^{\mathrm{a}}$

\begin{tabular}{|c|c|c|c|c|c|c|}
\hline & \multicolumn{3}{|c|}{ Placebo-controlled studies } & \multicolumn{3}{|c|}{ Active-controlled studies } \\
\hline & Placebo & $\begin{array}{l}\text { Eplerenone } \\
50 \mathrm{mg}\end{array}$ & $\begin{array}{l}\text { Eplerenone } \\
100 \mathrm{mg}\end{array}$ & Active & $\begin{array}{l}\text { Eplerenone } \\
50 \mathrm{mg}\end{array}$ & $\begin{array}{l}\text { Eplerenone } \\
100 \mathrm{mg}\end{array}$ \\
\hline Total N & 637 & 441 & 316 & 806 & 282 & 216 \\
\hline Age in years (SD) & $54.9(11.1)$ & $55.2(I I .2)$ & $53.3(9.6)$ & $56.7(I I .8)$ & $55.3(12.6)$ & $54.4(\mathrm{II} .0)$ \\
\hline \multicolumn{7}{|l|}{ Ethnicity (\%) } \\
\hline Caucasian & 55.4 & 62.6 & 52.5 & 75.7 & 79.1 & 72.7 \\
\hline Black & 22.1 & 13.4 & 18.4 & 20.3 & 14.9 & 22.2 \\
\hline Asian & 8.5 & 11.3 & 14.9 & 0.6 & 0.4 & 0.0 \\
\hline Hispanic & 13.5 & 11.8 & 13.3 & 3.0 & 5.7 & 4.6 \\
\hline Other & 0.5 & 0.9 & 0.9 & 0.4 & 0.0 & 0.5 \\
\hline Female gender (\%) & 50.1 & 48.1 & 44.6 & 48.3 & 49.3 & 47.2 \\
\hline \multicolumn{7}{|l|}{ BMI $\left(\mathbf{k g} / \mathbf{m}^{2}\right)$} \\
\hline Female & $29.4(5.9)$ & $29.9(5.9)$ & $30.0(6.4)$ & $31.1(6.7)$ & $30.5(5.6)$ & $31.0(6.2)$ \\
\hline Male & $29.2(4.6)$ & $29.4(5.7)$ & $28.7(4.3)$ & $29.3(4.4)$ & $29.2(5.5)$ & $29.7(4.1)$ \\
\hline \multicolumn{7}{|l|}{ Baseline blood pressure $(\mathrm{mmHg})$} \\
\hline Systolic & $151.8(12.0)$ & $152.8(13.0)$ & I54.I (13.7) & $156.5(14.4)$ & $153.2(14.0)$ & $153.7(14.4)$ \\
\hline Diastolic & 99.1 (3.9) & $99.3(4.2)$ & $100.4(4.6)$ & $97.5(7.1)$ & $98.3(5.5)$ & $98.8(5.6)$ \\
\hline Heart rate (bpm) & $72.7(9.3)$ & $72.6(8.9)$ & $73.2(8.8)$ & $72.5(9.4)$ & $73.5(9.6)$ & $72.9(8.6)$ \\
\hline eGFR ${ }^{b}$ in $\mathrm{mL} / \mathrm{min} / \mathrm{l} .73 \mathrm{~m}^{2}(\mathrm{SD})$ & $100.5(11.5)$ & $98.8(10.1)$ & $101.0(9.7)$ & $99.1(11.7)$ & $99.1(11.3)$ & $100.9(11.0)$ \\
\hline Potassium (mmol/L) & $4.3(0.4)$ & $4.2(0.4)$ & $4.2(0.4)$ & $4.2(0.4)$ & $4.2(0.3)$ & $4.2(0.4)$ \\
\hline History of cardiovascular disease ${ }^{c}(\%)$ & 11.6 & 12.5 & 14.6 & 20.1 & 19.5 & 17.6 \\
\hline Diabetes $^{\mathrm{d}}(\%)$ & 7.8 & 5.2 & 6.6 & 10.2 & 6.0 & 4.2 \\
\hline
\end{tabular}

Notes: ${ }^{a}$ Values are means $( \pm S D)$ unless otherwise stated. ${ }^{\mathrm{b}}$ Transformed data using the CKD-EPI for estimation of glomerular filtration rate. ${ }^{\mathrm{C}}$ Major cardiovascular exclusion criteria from participation in the clinical trials included recent history of Ml/acute coronary syndrome, intermittent claudication, cerebrovascular disease, severe valvular disease, NYHA classification II-IV chronic heart failure. Patients with Type I and Type II diabetes were excluded from studies 010 and 403 ; patients with Type I and uncontrolled Type II diabetes were excluded from studies 016, 019, 020, 022, 023, 024, 026 and 049; patients with uncontrolled Type I and Type II diabetes were excluded from study 015 .

Abbreviations: BMI, body mass index; CKD-EPI, Chronic Kidney Disease Epidemiology Collaboration; eGFR, estimated glomerular filtration rate; MI, myocardial infarction; NYHA, New York Heart Association.

Table 3 Change from baseline in seated SBP/DBP

\begin{tabular}{|c|c|c|c|c|c|}
\hline \multicolumn{6}{|c|}{ Placebo-controlled studies } \\
\hline & Placebo & $\begin{array}{l}\text { Eplerenone } \\
50 \mathrm{mg} \text { daily }\end{array}$ & $\begin{array}{l}\text { Eplerenone } \\
100 \text { mg daily }\end{array}$ & $\begin{array}{l}\text { Eplerenone } 50 \mathrm{mg} \\
\text { vs placebo }\end{array}$ & $\begin{array}{l}\text { Eplerenone } 100 \mathrm{mg} \\
\text { vs placebo }\end{array}$ \\
\hline $\begin{array}{l}\text { Mean change from } \\
\text { baseline in } \mathrm{BP}^{\mathrm{a}} \\
(\mathrm{SBP} / \mathrm{DBP})\end{array}$ & $-4.98 /-5.67$ & $-12.53 /-9.72$ & $-13.73 /-9.96$ & $-7.55 /-4.05$ & $-8.75 /-4.30$ \\
\hline $95 \% \mathrm{Cl}$ for SBP & $-6.03,-3.93$ & $-13.73,-11.33$ & $-15.22,-12.24$ & $-9.14,-5.96$ & $-10.57,-6.93$ \\
\hline $95 \% \mathrm{Cl}$ for DBP & $-6.30,-5.03$ & $-10.44,-8.99$ & $-10.86,-9.06$ & $-5.01,-3.09$ & $-5.39,-3.20$ \\
\hline$P$-value & & & & $<0.0001 /<0.0001$ & $<0.0001 /<0.0001$ \\
\hline \multicolumn{6}{|c|}{ Active-controlled studies } \\
\hline & $\begin{array}{l}\text { Active } \\
\text { treatment }\end{array}$ & $\begin{array}{l}\text { Eplerenone } \\
50 \text { mg daily }\end{array}$ & $\begin{array}{l}\text { Eplerenone } \\
100 \text { mg daily }\end{array}$ & $\begin{array}{l}\text { Eplerenone } 50 \mathrm{mg} \\
\text { vs active }\end{array}$ & $\begin{array}{l}\text { Eplerenone } 100 \mathrm{mg} \\
\text { vs active }\end{array}$ \\
\hline $\begin{array}{l}\text { Mean change from } \\
\text { baseline in } \mathrm{BP}^{\mathrm{a}}\end{array}$ & $-|3.28 /-9.3|$ & $-16.53 /-11.21$ & $-17.58 /-10.77$ & $-3.25 /-1.90$ & $-4.30 /-1.46$ \\
\hline $95 \% \mathrm{Cl}$ for SBP & $-14.29,-12.27$ & $-18.27,-14.79$ & $-19.58,-15.58$ & $-5.25,-1.25$ & $-6.56,-2.03$ \\
\hline $95 \% \mathrm{Cl}$ for DBP & $-9.91,-8.71$ & $-12.25,-10.17$ & $-11.96,-9.59$ & $-3.09,-0.71$ & $-2.81,-0.12$ \\
\hline$P$-value & & & & $0.0015 / 0.0018$ & $0.0002 / 0.0328$ \\
\hline
\end{tabular}

Note: aPooled least-square means and $95 \% \mathrm{Cl}$ based on a meta-analysis fixed-effects model with factors for study, treatment group, and baseline covariate.

Abbreviations: DBP, diastolic blood pressure; SBP, systolic blood pressure.

age and BMI influenced the efficacy results of changes in BP by $<0.2 \mathrm{mmHg}$ for all comparisons of eplerenone $50 \mathrm{mg}$ daily or eplerenone $100 \mathrm{mg}$ daily to placebo or the active comparator. Neither a history of CV diseases nor diabetes mellitus contributed significantly to the model.

\section{Safety findings}

Table 4 describes the treatment-emergent AEs occurring in at least $3 \%$ of patients from the safety analysis set (patients randomized and treated with at least one dose of study drug) in any group from the placebo- and the active-controlled studies, 
Table 4 Treatment-emergent adverse events

\begin{tabular}{|c|c|c|c|}
\hline \multicolumn{4}{|l|}{ Placebo-controlled studies } \\
\hline & Placebo & Eplerenone $\mathbf{5 0} \mathbf{~ m g}$ daily & Eplerenone 100 mg daily \\
\hline $\mathrm{N}$ & 729 & 512 & 436 \\
\hline No. of patients with serious AEs (\%) & $10(1.4)$ & $10(2.0)$ & $2(0.5)$ \\
\hline No. of patients who discontinued due to AEs (\%) & $15(2.1)$ & $22(4.3)$ & $7(1.6)$ \\
\hline No. of patients who discontinued due to serious AEs (\%) & $2(0.3)$ & $6(1.2)$ & $\mathrm{I}(0.2)$ \\
\hline \multicolumn{4}{|l|}{ AEs, no. of events (\%) } \\
\hline Arthralgia & $8(1.1)$ & $13(2.5)$ & $14(3.2)$ \\
\hline Dizziness & $26(3.6)$ & $2 I(4 . I)$ & $23(5.3)$ \\
\hline Headache & $132(18.1)$ & $78(15.2)$ & $75(17.2)$ \\
\hline Diarrhea & $22(3.0)$ & II (2.I) & $9(2.1)$ \\
\hline Nausea & $20(2.7)$ & $22(4.3)$ & $14(3.2)$ \\
\hline Hypercholesterolemia & $3(0.4)$ & $6(1.2)$ & $14(3.2)$ \\
\hline Sinusitis & $15(2.1)$ & $13(2.5)$ & $17(3.9)$ \\
\hline Upper respiratory tract infection & $40(5.5)$ & $32(6.3)$ & $38(8.7)$ \\
\hline Bronchitis & $12(1.6)$ & $8(1.6)$ & $13(3.0)$ \\
\hline Edema peripheral & $23(3.2)$ & $13(2.5)$ & $9(2.1)$ \\
\hline Fatigue & $18(2.5)$ & $14(2.7)$ & $14(3.2)$ \\
\hline \multicolumn{4}{|l|}{ Active-controlled studies } \\
\hline & Active & Eplerenone 50 mg daily & Eplerenone 100 mg daily \\
\hline $\mathrm{N}$ & 892 & 349 & 274 \\
\hline No. of patients with serious AEs (\%) & $24(2.7)$ & $15(4.3)$ & $5(1.8)$ \\
\hline No. of patients who discontinued due to AEs (\%) & 7I (8.0) & $35(10.0)$ & $15(5.5)$ \\
\hline No. of patients who discontinued due to serious AEs (\%) & II (I.2) & $8(2.3)$ & $\mathrm{I}(0.4)$ \\
\hline \multicolumn{4}{|l|}{$A E$, no. of events $(\%)^{a}$} \\
\hline Dizziness & $45(5.0)$ & $16(4.6)$ & $14(5.1)$ \\
\hline Headache & $151(16.9)$ & $42(12.0)$ & $58(21.2)$ \\
\hline Diarrhea & $33(3.7)$ & $10(2.9)$ & $4(1.5)$ \\
\hline Nausea & $30(3.4)$ & $12(3.4)$ & II (4.0) \\
\hline Hypercholesterolemia & $6(0.7)$ & $6(1.7)$ & $9(3.3)$ \\
\hline Hyperglycemia & $22(2.5)$ & $5(1.4)$ & $2(0.7)$ \\
\hline Creatine phosphokinase increased & $28(3.1)$ & $8(2.3)$ & $9(3.3)$ \\
\hline Coughing & $27(3.0)$ & $8(2.3)$ & $5(1.8)$ \\
\hline Sinusitis & $22(2.5)$ & $7(2.0)$ & $16(5.8)$ \\
\hline Upper respiratory tract infection & $81(9.1)$ & $24(6.9)$ & $24(8.8)$ \\
\hline Bronchitis & $23(2.6)$ & $5(1.4)$ & $9(3.3)$ \\
\hline
\end{tabular}

Note: a AEs (WHO-ART dictionary Preferred Terms) occurring in at least $3 \%$ of patients in any group.

Abbreviations: AEs, adverse events; WHO-ART, World Health Organization Adverse Reaction Terminology.

respectively. No deaths were reported; SAEs occurred in $0.5 \%-4.3 \%$ of eplerenone-treated patients, compared with $1.4 \%$ of placebo-treated patients and $2.7 \%$ of active-treatment comparators. In eplerenone-treated patients, $1.6 \%-10 \%$ discontinued because of treatment-emergent AEs $(0.2 \%-2.3 \%$ due to SAEs) compared with $2.1 \%$ of placebo-treated patients $(0.3 \%$ due to SAEs) and $8.0 \%$ of active-treatment comparators (1.2\% due to SAEs). Headache was the most common AE for patients in any group (15.2\%-21.2\% in the eplerenone groups, $16.9 \%$ in the active control, and $18.1 \%$ in the placebo group).

At the end of treatment, the mean change in serum potassium level from baseline ranged from 0.09 to 0.13 $\mathrm{mmol} / \mathrm{L}$ in the eplerenone groups, when compared with
0.00 (SE of \pm 0.013 ) $\mathrm{mmol} / \mathrm{L}$ in the placebo group and the active-control group. A serum potassium level $>5.5 \mathrm{mmol} / \mathrm{L}$ was reported in $1.2 \%-1.9 \%$ of eplerenone-treated patients, $0.8 \%$ in the placebo group, and $1.6 \%$ in the active-control group. A serum potassium level $>6.0 \mathrm{mmol} / \mathrm{L}$ occurred in $0.0 \%-0.4 \%$ in the eplerenone groups, $0.4 \%$ in the placebo group, and $0.1 \%$ in the active-control group. A serum potassium level $<3.5 \mathrm{mmol} / \mathrm{L}$ was reported in $1.0 \%-1.6 \%$ in the eplerenone group, $3.1 \%$ in the placebo group, and $6.5 \%$ in the active-control group. In Table 5, changes in serum potassium values are presented. Because patients with diabetes are considered at increased risk of hyperkalemia, ${ }^{26}$ serum potassium level results for that specific patient population are also presented. 
A

LS means of the difference between eplerenone $50 \mathrm{mg}$ and placebo in change from baseline in seSBP at end of study

placebo-controlled studies-per-protocol set

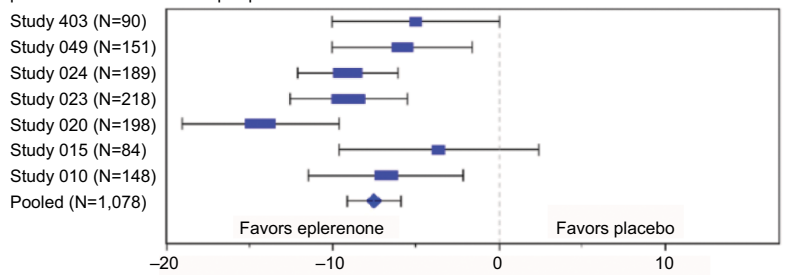

LS means of the difference between eplerenone $50 \mathrm{mg}$ and placebo in change from baseline in SeDPB at end of study placebo-controlled studies-per-protocol set

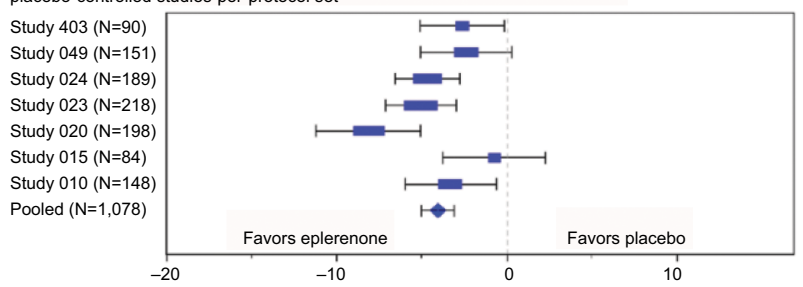

B

LS means of the difference between eplerenone $50 \mathrm{mg}$ and active control in change from baseline in seSBP at end of study

active-controlled studies-per-protocol set

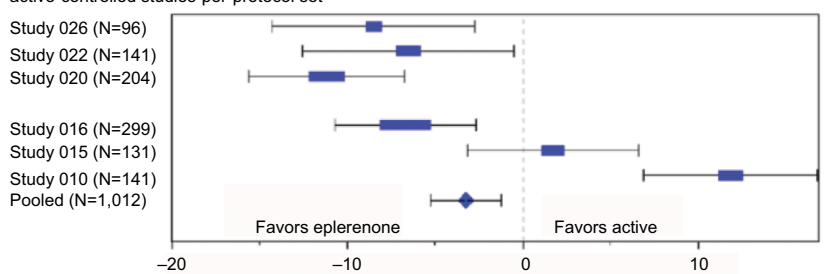

LS means of the difference between eplerenone $50 \mathrm{mg}$ and active control in change from baseline in seDPB at end of study active-controlled studies-per-protocol set

Study $026(\mathrm{~N}=96)$ Study $022(\mathrm{~N}=141)$ Study $020(\mathrm{~N}=204)$

Study $016(\mathrm{~N}=299)$ Study $015(\mathrm{~N}=131)$ Study $010(\mathrm{~N}=141)$ Pooled $(\mathrm{N}=1,012)$

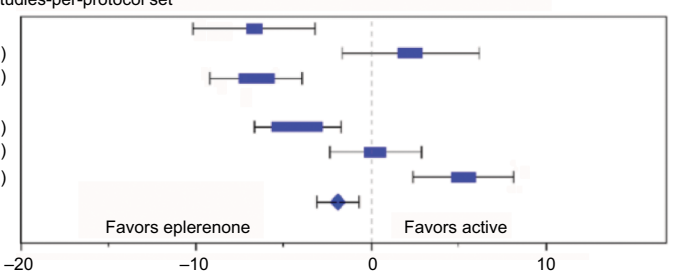

LS means of the difference between eplerenone $100 \mathrm{mg}$ and placebo in change from baseline in seSBP at end of study placebo-controlled studies-per-protocol set

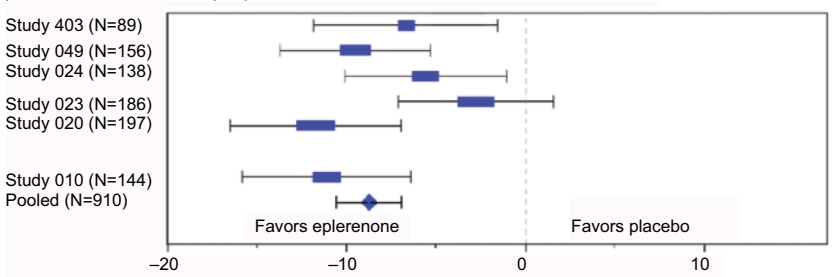

LS means of the difference between eplerenone $100 \mathrm{mg}$ and placebo in change from baseline in seDPB at end of study placebo-controlled studies-per-protocol set

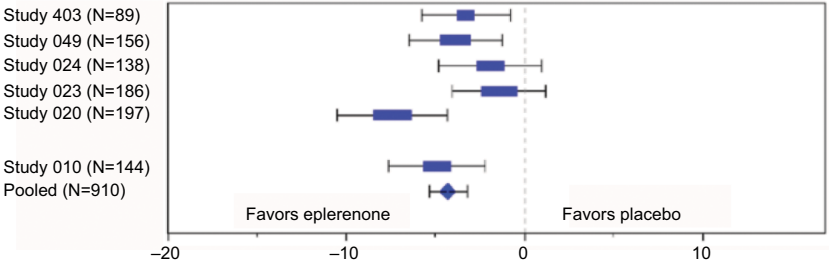

LS means of the difference between eplerenone 100
in change from baseline in seSBP at end of study

active-controlled studies-per-protocol set

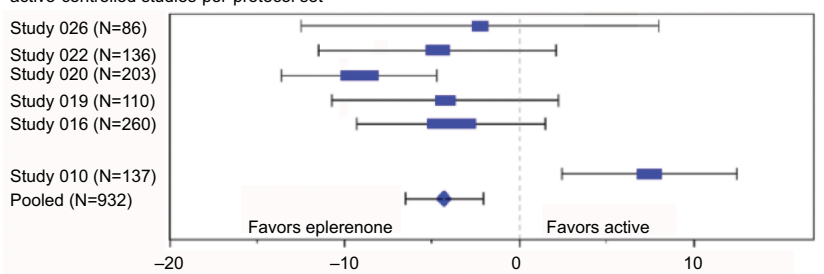

LS means of the difference between eplerenone $100 \mathrm{mg}$ and active control in change from baseline in seDPB at end of study

active-controlled studies-per-protocol set

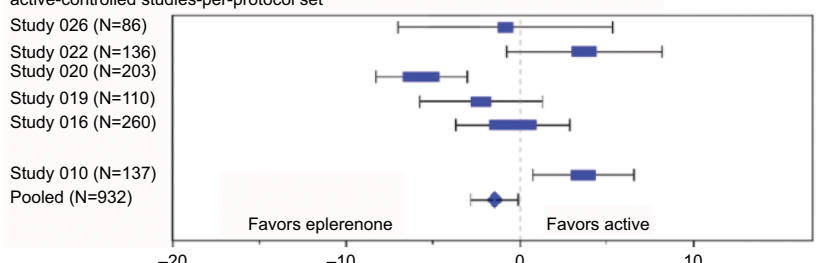

Figure 2 Change from baseline in seated SBP/DBP: (A) placebo-controlled studies and (B) active-controlled studies.

Notes: LS Means model includes Study, Treatment, and Baseline BP. The per-protocol analysis set included all patients who were randomly assigned to treatment (eplerenone $50 \mathrm{mg}$ daily, eplerenone $100 \mathrm{mg}$ daily, or active control), who had a baseline primary efficacy evaluation, took at least one dose of study drug, and received at least 6 weeks of fixed dose of study drug. Weight of blue symbol is defined as percentage study contribution to total pooled results. Study 015 is not represented in the eplerenone $100 \mathrm{mg}$ analysis due to lack of treatment arm with that dosage. Study 019 is not represented in the eplerenone $50 \mathrm{mg}$ analysis due to lack of treatment arm with that dosage. See Table 3 for the $95 \%$ confidence intervals of differences in seated SBP/DBP between eplerenone and placebo.

\section{Discussion}

In this pooled analysis of patient-level data from the Phase III trials, only the data from the use of eplerenone at doses of 50 and $100 \mathrm{mg}$ per day for a minimum of 6 weeks were compared against placebo (seven trials) or active comparators (seven trials) also with a stable dose of medication for a minimum of 6 weeks. The goal of this specific analysis was to document the efficacy of eplerenone at the approved doses for the treatment of primary hypertension, after stable dosing when the maximum pharmacodynamic response should have been reached. The safety evaluation of this analysis included all randomized patients who took at least one dose of study drug, therefore, documenting safety in all treated patients, not just the ones who were able to tolerate therapy for a minimum of 6 weeks. In placebo-controlled trials, eplerenone 50 and $100 \mathrm{mg}$ significantly lowered the BP compared with placebo. Similarly, eplerenone significantly lowered the BP more than the active comparators. These results are similar to those seen in study-level pooled analyses including dosages of eplerenone from 50 to $400 \mathrm{mg}$ daily. ${ }^{27,28}$ Our descriptive secondary endpoint indicated that the percentage of patients controlled to the target BP of 140/90 was numerically greater 
Table 5 Potassium laboratory values

\begin{tabular}{|c|c|c|c|}
\hline \multicolumn{4}{|l|}{ Placebo-controlled studies } \\
\hline & Placebo & $\begin{array}{l}\text { Eplerenone } \\
50 \mathrm{mg} \text { daily }\end{array}$ & $\begin{array}{l}\text { Eplerenone } \\
100 \mathrm{mg} \text { daily }\end{array}$ \\
\hline $\mathrm{N}$ & 715 & 489 & 430 \\
\hline Change from baseline in serum potassium (mean $\pm \mathrm{SE}$ ) & $0.00(0.013)$ & $0.13(0.017)$ & $0.13(0.018)$ \\
\hline No. of patients with $\mathrm{K}+<3.5 \mathrm{mmol} / \mathrm{L}(\%)$ & $22(3.1)$ & $5(1.0)$ & $5(1.2)$ \\
\hline No. of patients with $\mathrm{K}+>5.5 \mathrm{mmol} / \mathrm{L}(\%)$ & $6(0.8)$ & $6(1.2)$ & $6(1.2)$ \\
\hline No. of patients with $\mathrm{K}+>6.0 \mathrm{mmol} / \mathrm{L}(\%)$ & $3(0.4)$ & 00.0 & $\mathrm{I}(0.2)$ \\
\hline No. of patients with hypokalemia reported as an adverse event by the investigators (\%) & $2(0.3)$ & $\mathrm{I}(0.2)$ & $2(0.5)$ \\
\hline No. of patients with hyperkalemia reported as an adverse event by the investigators (\%) & $3(0.4)$ & $7(1.4)$ & $2(0.5)$ \\
\hline No. of diabetic patients with $\mathrm{K}+<3.5 \mathrm{mmol} / \mathrm{L}(\%)$ & $0 / 57(0.0)$ & $0 / 26(0.0)$ & $0 / 30(0.0)$ \\
\hline No. of diabetic patients with $\mathrm{K}+>5.5 \mathrm{mmol} / \mathrm{L}(\%)$ & $\mathrm{I} / 57(\mathrm{I} .8)$ & $1 / 26(3.8)$ & $0 / 30(0.0)$ \\
\hline No. of diabetic patients with $\mathrm{K}+>6.0 \mathrm{mmol} / \mathrm{L}$ (\%) & $0 / 57(0.0)$ & $0 / 26(0.0)$ & $0 / 30(0.0)$ \\
\hline \multicolumn{4}{|l|}{ Active-controlled studies } \\
\hline & Active & Eplerenone & Eplerenone \\
\hline & & 50 mg daily & 100 mg daily \\
\hline $\mathrm{N}$ & 876 & 322 & 266 \\
\hline Change from baseline in serum potassium (mean $\pm \mathrm{SE}$ ) & $0.00(0.013)$ & $0.09(0.020)$ & $0.11(0.024)$ \\
\hline No. of patients with $\mathrm{K}+<3.5 \mathrm{mmol} / \mathrm{L}(\%)$ & $57(6.5)$ & $5(1.6)$ & $4(1.5)$ \\
\hline No. of patients with $\mathrm{K}+>5.5 \mathrm{mmol} / \mathrm{L}(\%)$ & $14(1.6)$ & $6(1.9)$ & $5(1.9)$ \\
\hline No. of patients with $\mathrm{K}+>6.0 \mathrm{mmol} / \mathrm{L}(\%)$ & $\mathrm{I}(0.1)$ & $0(0.0)$ & $\mathrm{I}(0.4)$ \\
\hline No. of patients with hypokalemia reported as an adverse event by the investigators (\%) & $8(0.9)$ & I $(0.3)$ & $2(0.7)$ \\
\hline No. of patients with hyperkalemia reported as an adverse event by the investigators (\%) & $3(0.3)$ & $\mathrm{I}(0.3)$ & $4(1.5)$ \\
\hline No. of diabetic patients with $\mathrm{K}+<3.5 \mathrm{mmol} / \mathrm{L}(\%)$ & $4 / 85(4.7)$ & $0 / 20(0.0)$ & $0 / 10(0.0)$ \\
\hline No. of diabetic patients with $\mathrm{K}+>5.5 \mathrm{mmol} / \mathrm{L}(\%)$ & $1 / 85(1.2)$ & $2 / 20(10.0)$ & $0 / 10(0.0)$ \\
\hline No. of diabetic patients with $\mathrm{K}+>6.0 \mathrm{mmol} / \mathrm{L}(\%)$ & $0 / 85(0.0)$ & $0 / 20(0.0)$ & $0 / 10(0.0)$ \\
\hline
\end{tabular}

with eplerenone than with placebo or active comparators. In the placebo-controlled studies, approximately $30 \%$ of patients were below target while on placebo, which is a common observation particularly in short-term studies. ${ }^{29}$ In both placebo-controlled and active-controlled studies, the responder rate between eplerenone $50 \mathrm{mg}$ daily and $100 \mathrm{mg}$ daily suggests an apparent lack of dose response between the two approved doses, that is, response to the higher dose of eplerenone does not seem greater compared with the lower dose of eplerenone. However, Phase II studies are the studies generally used to assess dose-response associations in which patients are randomized to fixed doses of an antihypertensive agent. Only Phase III studies were used in this analysis and many of the studies used a design in which the study drugs were titrated to target BP and (three for the placebo-controlled studies and five for the active-controlled studies) in which each level of titration selects patients who are progressively more resistant to treatment. This difference in study design is responsible for the apparent blunting of the dose-response effect.

Overall, eplerenone was well tolerated; the tolerability was similar to that of placebo or active comparators. In the placebo-controlled studies, the most common AE was headache, and the percentage of patients with headache was similar in the eplerenone-treated groups compared to the placebo-treated group. Some AEs appeared to be less common in the eplerenone 100 mg-treated patients compared with the eplerenone $50 \mathrm{mg}$-treated patients, but this may be the result of bias caused by the inclusion of titrate-to-target studies; patients would only be titrated up in dose if they had tolerated the lower dose thereby preselecting tolerant patients to receive higher doses. Despite the limitation of the titrate-to-effect studies regarding the evaluation of the dose-response for safety or efficacy, this trial design provides valid information about the effectiveness and tolerability for the clinicians, as it is indicative of how clinicians treat patients in a "real-world" setting.

The incidence of hyperkalemia was low and similar across all treatment arms. These results suggest that in patients with normal renal function, hyperkalemia is not frequently observed in the regulatory-approved doses. It must be noted that patients in this analysis had an estimated glomerular filtration rate (eGFR) of approximately $100 \mathrm{~mL} / \mathrm{min} / 1.73 \mathrm{~m}^{2}$ and that patients with an eGFR $<50 \mathrm{~mL} / \mathrm{min} / 1.73 \mathrm{~m}^{2}$ or serum potassium $>5.0 \mathrm{mmol} / \mathrm{L}$ before treatment were not enrolled in most of the hypertension studies. 
The strength of this pooled analysis stems from the use of patient-level data that allowed the comparison of BP reductions from specific doses of eplerenone taken long enough for the pharmacologic action to reach steady state; similarly, the safety and tolerability of eplerenone and the comparators were also examined using patient-level rather than study-level data.

Despite the strengths of this patient-level pooled analysis, there are limitations. The population with diabetes was too small to make any definitive statements about the safety of eplerenone regarding hyperkalemia in that subgroup. The efficacy analysis of patients with diabetes, assessed by ANCOVA, suggested that the BP response to eplerenone was similar compared to the general population. However, the sample size of patients with diabetes prevented reaching this conclusion with great certainty. Patients with diabetes represent a large group who might receive eplerenone due to their relatively lower rate of reaching recommended target BPs and their higher risk of developing coronary artery disease, heart failure, and chronic kidney disease.

The studies from which the safety data were extracted were designed primarily to evaluate the efficacy of eplerenone and the comparative agents. Safety, tolerability, and adverse effects were secondary outcomes; it is certainly not possible to formally compare tolerability and safety between specific classes of antihypertensive medications, based on the relatively small number of studies for each individual comparative agent included in the analysis. Also, given that these comparative studies were conducted in the late 1990s and early 2000s, there are no studies with some of the newer medications used now such as telmisartan or olmesartan. However, a report using NHANES 2001-2010 data stated that the most commonly used antihypertensive drugs were lisinopril (20.1\%), metoprolol (15.1\%), hydrochlorothiazide (10.7\%), and amiloride $(10.4 \%) .{ }^{30}$ The most commonly used A-II antagonist was valsartan at 5.2\%, so the data from the Eplerenone Hypertension Clinical Program used in this pooled analysis can still likely be considered contemporary.

Clinicians may wonder how eplerenone compares to spironolactone, another mineralocorticoid antagonist, for the treatment of primary hypertension. Eplerenone is an aldosterone receptor antagonist that binds selectively to human mineralocorticoid receptors relative to its binding to glucocorticoid, progesterone, and androgen receptors. In vitro, eplerenone has a markedly lower binding affinity for these latter receptors compared with spironolactone, thus reducing the risk of endocrine AEs (eg, gynecomastia, breast pain, impotence, menstrual disorders, dyslipidemia, or increased blood sugar). There are limited clinical data with respect to the dosage equivalency between eplerenone and spironolactone. One study comparing eplerenone to spironolactone was included in this pooled analysis. Weinberger et al evaluated the safety and efficacy of eplerenone and spironolactone in patients with mild-to-moderate hypertension. ${ }^{31}$ Changes from baseline in SBP and DBP for eplerenone $100 \mathrm{mg}$ daily were approximately $50 \%-75 \%$ of those observed with the spironolactone $100 \mathrm{mg}$ daily. The inclusion of spironolactone as a positive control in this placebo-controlled study confirmed and validated the BP-lowering effects of eplerenone. However, the primary efficacy variable was the change from baseline in DBP compared with placebo, and therefore the study was not powered to detect differences between the two MRA groups on efficacy or on AEs. There is currently no comparative mortality and morbidity data for eplerenone vs spironolactone in the treatment of primary hypertension; therefore, the use of one agent over the other should be guided by pharmacologic profiles and individual patient considerations and needs.

This patient-level pooled analysis assessing specific dosages provided a clearer picture of what physicians and patients can expect when using approved doses of eplerenone compared to other antihypertensive agents in regards to BP reduction as well as tolerability and safety.

\section{Conclusion}

This individual patient-level pooled analysis provided robust evidence that eplerenone, at $50 \mathrm{mg}$ or $100 \mathrm{mg}$ daily, evaluated in monotherapy studies or studies in combination with other antihypertensive agents, was effective in lowering BP in patients with mild-to-moderate hypertension and was well tolerated. This effect was slightly greater for eplerenone compared with the other antihypertensive agents evaluated. The present analysis suggests that selective mineralocorticoid receptor blockade with eplerenone can be safely used and is an effective therapeutic option for patients with hypertension, which may be of particular importance in those individuals in whom the blockade of aldosterone effects could prove clinically beneficial.

\section{Acknowledgments}

This analysis was sponsored by Pfizer. The studies included in this pooling analysis were sponsored by G.D. Searle \& Co. and Pharmacia, which were acquired by Pfizer. 


\section{Disclosure}

Drs MF, BB, PA, KL, and JV report being employees of Pfizer and receiving stock options and travel reimbursements from Pfizer. Dr EB is a paid consultant for several companies that manufacture drugs used in the treatment of hypertension and in this capacity has received travel assistance to attend advisory board meetings. She has also received honoraria and other compensation from several companies for conducting research, as well as speaker fees and educational grants. The authors report no other conflicts of interest in this work.

\section{References}

1. Go AS, Bauman MA, Coleman King SM, et al. An effective approach to high blood pressure control: A science advisory from the American Heart Association, the American College of Cardiology, and the Centers for Disease Control and Prevention. J Am Coll Cardiol. 2014;63(12):1230-1238.

2. Kostis JB, Cabrera J, Cheng JQ, et al. Association between chlorthalidone treatment of systolic hypertension and long-term survival. JAMA. 2011;306(23):2588-2593.

3. Mcalister FA, Wilkins K, Joffres M, et al. Changes in the rates of awareness, treatment and control of hypertension in Canada over the past two decades. CMAJ. 2011;183(9):1007-1013.

4. Tu K, Campbell NRC, Duong-Hua M, Mcalister FA. Hypertension management in the elderly has improved - Ontario prescribing trends, 1994-2002. Hypertension. 2005;45:1113-1118.

5. Oliveras A, Armario P, Lucas S, de La Sierra A, COMBICONTROL Study Investigators. Blood pressure control is similar in treated hypertensive patients with optimal or with high-normal albuminuria. Am J Hypertens. 2014;27(9):1185-1190.

6. Clinical practice guidelines for the management of hypertension in the community: a statement by the American Society of Hypertension and the International Society of Hypertension. J Clin Hypertens. 2014;16:14-26.

7. SPRINT Research Group, Wright JT, Williamson JD, et al. A randomized trial of intensive versus standard blood-pressure control. $N$ Engl J Med. 2015;373(22):2103-2116.

8. ACCORD Study Group, Cushman WC, Evans GW, et al. Effects of intensive blood-pressure control in type 2 diabetes mellitus. $N$ Engl J Med. 2010;362(17):1575-1585.

9. Burgess E. Eplerenone in hypertension. Expert Opin Pharmacother. 2004;5(12):2573-2581.

10. Jansen PM, Frenkel WJ, van den Born BJ, et al. Determinants of blood pressure reduction by eplerenone in uncontrolled hypertension. J Hypertens. 2013;31(2):404-413.

11. Karns AD, Bral JM, Hartman D, Peppard T, Schumacher C. Study of aldosterone synthase inhibition as an add-on therapy in resistant hypertension. J Clin Hypertens. 2013;15(3):186-192.
12. Williams B, Macdonald TM, Morant S, et al. Spironolactone versus placebo, bisoprolol, and doxazosin to determine the optimal treatment for drug-resistant hypertension (PATHWAY-2): a randomised, doubleblind, crossover trial. Lancet. 2015;386(10008):2059-2068.

13. Bomback AS, Klemmer PJ. The incidence and implications of aldosterone breakthrough. Nat Clin Pract Nephrol. 2007;3(9):486-492.

14. Zannad F, McMurray JJ, Krum H, et al. Eplerenone in patients with systolic heart failure and mild symptoms. NEngl J Med. 2011;364(1):11-21.

15. Pitt B, Zannad F, Remme WJ, et al. The effect of spironolactone on morbidity and mortality in patients with severe heart failure. Randomized Aldactone Evaluation Study Investigators. $N$ Engl J Med. 1999;341(10):709-717.

16. Pitt B, Remme W, Zannad F, et al. Eplerenone, a selective aldosterone blocker, in patients with left ventricular dysfunction after myocardial infarction. N Engl J Med. 2003;348(14):1309-1321.

17. Batterink J, Stabler SN, Tejani AM, Fowkes CT. Spironolactone for hypertension. Cochrane Database Syst Rev. 2010(8):CD008169.

18. Croom KF, Perry CM. Eplerenone: a review of its use in essential hypertension. Am J Cardiovasc Drugs. 2005;5(1):51-69.

19. Rafestin-Oblin ME, Rudolph A, Faggart J. Eplerenone: a selective aldosterone blocker. J Hypertens. 2003;21(Suppl 4):202.

20. de Gasparo M, Joss U, Ramjoué HP, et al. Three new epoxy-spirolactone derivatives: characterization in vivo and in vitro. J Pharmacol Exp Ther. 1987;240(2):650-656.

21. Garthwaite SM, McMahon EG. The evolution of aldosterone antagonists. Mol Cell Endocrinol. 2004;217(1-2):27-31.

22. Pfizer Canada Inc., INSPRA Product Monograph. 2014.

23. Yamaji M, Tsutamoto T, Kawahara C, Nishiyama K, Yamamoto T, Fujii M, Horie M. Effect of eplerenone versus spironolactone on cortisol and hemoglobin A1(c) levels in patients with chronic heart failure. Am Heart J. 2010;160(5):915-921.

24. Lainscak M, Pelliccia F, Rosano G, et al. Safety profile of mineralocorticoid receptor antagonists: spironolactone and eplerenone. Int $J$ Cardiol. 2015;200:25-29.

25. Jankowska EA, Biel B, Majda J, et al. Anabolic deficiency in men with chronic heart failure: prevalence and detrimental impact on survival. Circulation. 2006;114:1829-1837.

26. Pfizer Inc., INSPRA US Package Insert. 2016.

27. Pelliccia F, Patti G, Rosano G, Greco C, Gaudio C. Efficacy and safety of eplerenone in the management of mild to moderate arterial hypertension: systematic review and meta-analysis. Int J Cardiol. 2014;177(1):219-228.

28. Tam TS, Wu MH, Masson SC, et al. Eplerenone for hypertension. Cochrane Database Syst Rev. 2017;2:CD008996.

29. Preston RA, Materson BJ, Reda DJ, Williams DW. Placebo-associated blood pressure response and adverse effects in the treatment of hypertension: observations from a Department of Veterans Affairs Cooperative Study. Arch Intern Med. 2000;160(10):1449-1454.

30. Gu Q, Burt VL, Dillon CF, Yoon S. Trends in antihypertensive medication use and blood pressure control among United States adults with hypertension. The National Health and Nutrition Evaluation Survey, 2001-2010. Circulation. 2012;126(17):2105-2114.

31. Weinberger $\mathrm{MH}$ et al. Eplerenone, a selective aldosterone blocker, in mild-to-moderate hypertension. Am J Hypertens. 2002;15:709-716. 


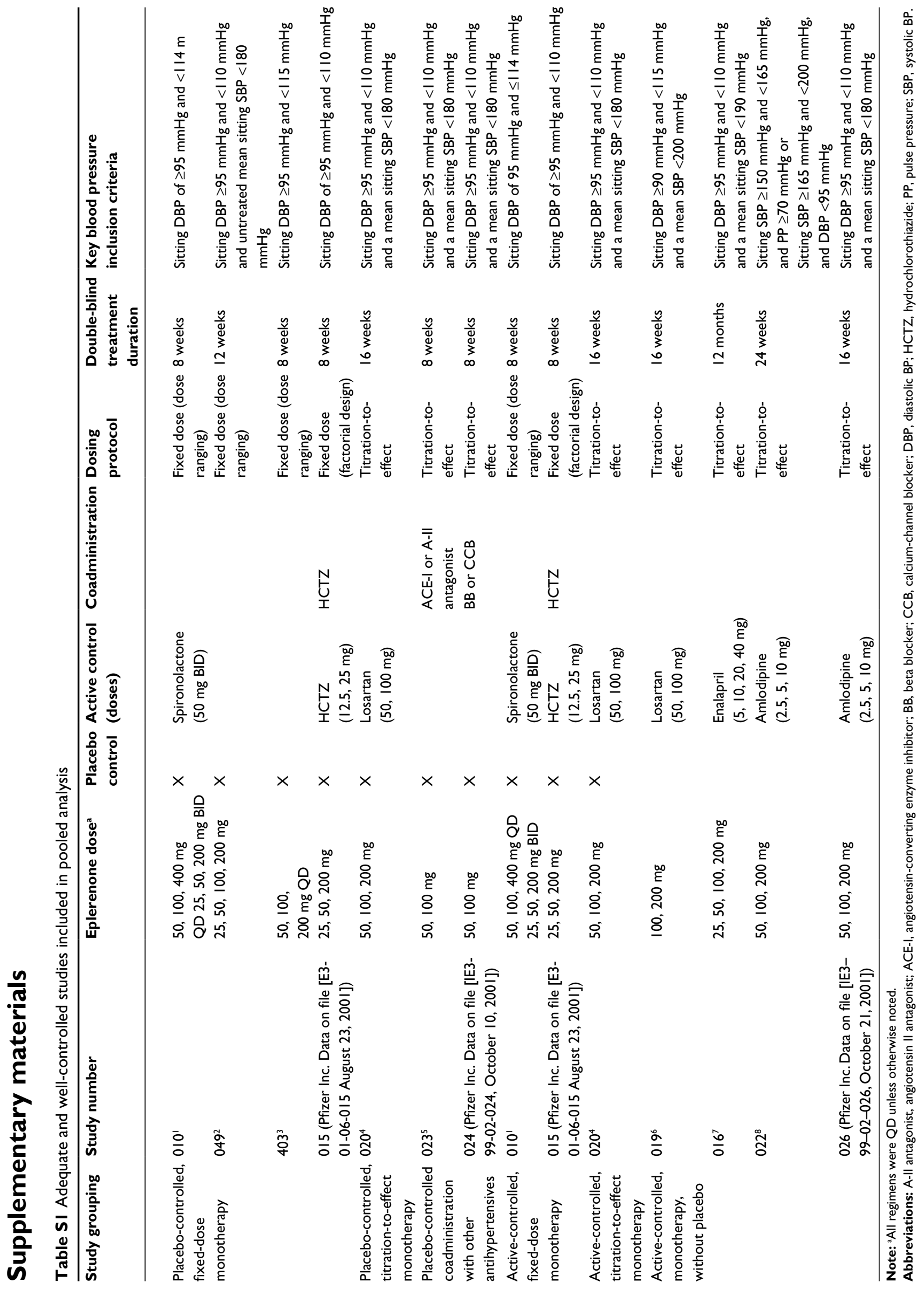


Table S2 Other controlled studies not included in pooled analysis

\begin{tabular}{|c|c|c|c|c|c|c|c|}
\hline Study grouping & Study & $\begin{array}{l}\text { Eplerenone } \\
\text { doses }\end{array}$ & $\begin{array}{l}\text { Active control } \\
\text { doses }\end{array}$ & $\begin{array}{l}\text { Open-label } \\
\text { additional } \\
\text { antihypertensives }\end{array}$ & $\begin{array}{l}\text { Dosing } \\
\text { protocol }\end{array}$ & $\begin{array}{l}\text { Double-blind } \\
\text { treatment } \\
\text { duration }\end{array}$ & $\begin{array}{l}\text { Reason for not } \\
\text { including in } \\
\text { pooled analysis }\end{array}$ \\
\hline $\begin{array}{l}\text { Secondary } \\
\text { hypertension } \\
\text { due to primary } \\
\text { hyperaldosteronism }\end{array}$ & $018^{9}$ & $\begin{array}{l}100,200,300 \\
\mathrm{mg}\end{array}$ & & $\begin{array}{l}\text { Spironolactone } \\
(75,150,225 \mathrm{mg})\end{array}$ & & $\begin{array}{l}\text { Titration-to- } \\
\text { effect } \\
16 \text { weeks }\end{array}$ & $\begin{array}{l}\text { Study population } \\
\text { outside approved } \\
\text { indication }\end{array}$ \\
\hline \multirow[t]{3}{*}{$\begin{array}{l}\text { Target organ } \\
\text { damage }\end{array}$} & $017^{10}$ & $\begin{array}{l}50 \rightarrow 100 \rightarrow \\
200 \mathrm{mg} \text { QD }\end{array}$ & $\begin{array}{l}\text { Enalapril }(10 \rightarrow 20 \rightarrow 40 \\
\mathrm{mg} \text { QD) } \\
\text { OR } \\
\text { Enalapril } 10 \mathrm{mg} \text { QD } \\
\text { with eplerenone } 50 \\
\mathrm{mg} \rightarrow 100 \mathrm{mg} \rightarrow 200 \\
\mathrm{mg} \text { QD }\end{array}$ & HCTZ, amlodipine & $\begin{array}{l}\text { Forced up- } \\
\text { titration }\end{array}$ & 9 months & $\begin{array}{l}\text { Study conducted } \\
\text { in hypertensive } \\
\text { patients with } \\
\text { left ventricular } \\
\text { hypertrophia, a } \\
\text { subpopulation not } \\
\text { included in label }\end{array}$ \\
\hline & $\begin{array}{l}\text { 02I (Pfizer } \\
\text { Inc. Data } \\
\text { on file } \\
\text { [IE3-99- } \\
02-02 I \text {, } \\
\text { October } \\
\text { 19, 200I]) }\end{array}$ & $\begin{array}{l}50 \rightarrow 100 \rightarrow \\
200 \mathrm{mg} \text { QD }\end{array}$ & $\begin{array}{l}\text { Enalapril }(10 \rightarrow 20 \rightarrow 40 \\
\mathrm{mg} \text { QD) } \\
\text { OR } \\
\text { Enalapril } 10 \mathrm{mg} \text { QD } \\
\text { with eplerenone } 50 \\
\mathrm{mg} \rightarrow 100 \mathrm{mg} \rightarrow 200 \\
\mathrm{mg} \text { QD }\end{array}$ & HCTZ, amlodipine & $\begin{array}{l}\text { Forced up- } \\
\text { titration }\end{array}$ & 24 weeks & $\begin{array}{l}\text { Study conducted } \\
\text { in hypertensive } \\
\text { patients } \\
\text { with MAU, a } \\
\text { subpopulation } \\
\text { contraindicated } \\
\text { in label }\end{array}$ \\
\hline & $067^{11}$ & $\begin{array}{l}50,100 \mathrm{mg} \\
\text { QD }\end{array}$ & $\begin{array}{l}\text { Enalapril ( } 20 \mathrm{mg} \text { QD) } \\
\text { OR } \\
\text { Enalapril } 20 \mathrm{mg} \\
\text { QD with either } \\
\text { eplerenone } 50 \mathrm{mg} \\
\text { QD, or } 100 \mathrm{mg} \text { QD }\end{array}$ & Amlodipine & Fixed dose & 12 weeks & $\begin{array}{l}\text { Study conducted } \\
\text { in hypertensive } \\
\text { patients } \\
\text { with MAU, a } \\
\text { subpopulation } \\
\text { contraindicated } \\
\text { in label }\end{array}$ \\
\hline
\end{tabular}

Abbreviations: HCTZ, hydrochlorothiazide; MAU, microalbuminuria.

Table S3 Uncontrolled studies not included in pooled analysis

\begin{tabular}{|c|c|c|c|c|c|c|c|c|}
\hline $\begin{array}{l}\text { Study } \\
\text { grouping }\end{array}$ & Study & Dose $^{a}$ & $\begin{array}{l}\text { Placebo } \\
\text { control }\end{array}$ & $\begin{array}{l}\text { Active } \\
\text { control } \\
\text { (doses) }\end{array}$ & Coadministration & $\begin{array}{l}\text { Dosing } \\
\text { protocol }\end{array}$ & $\begin{array}{l}\text { Treatment } \\
\text { duration }\end{array}$ & $\begin{array}{l}\text { Reason for not } \\
\text { including in } \\
\text { pooled analysis }\end{array}$ \\
\hline \multirow[t]{2}{*}{$\begin{array}{l}\text { Open-label, } \\
\text { safety }\end{array}$} & $025^{12}$ & $\begin{array}{l}50,100 \\
200 \mathrm{mg}\end{array}$ & None & None & $\begin{array}{l}\text { Various antihypertensives } \\
\text { (if BP uncontrolled with } \\
\text { 200-mg dose) }\end{array}$ & $\begin{array}{l}\text { Titration-to- } \\
\text { effect }\end{array}$ & 14 months & $\begin{array}{l}\text { Not a controlled } \\
\text { study }\end{array}$ \\
\hline & $\begin{array}{l}\text { 06I (Pfizer Inc. Data on file } \\
\text { [JE3-0I-02-06 I -09 June } \\
\text { 2005]) }\end{array}$ & $\begin{array}{l}50,100 \\
200 \mathrm{mg}\end{array}$ & None & None & $\begin{array}{l}\text { Various antihypertensives } \\
\text { (if BP uncontrolled with } \\
\text { 200-mg dose) }\end{array}$ & $\begin{array}{l}\text { Titration-to- } \\
\text { effect }\end{array}$ & 12 months & $\begin{array}{l}\text { Not a controlled } \\
\text { study }\end{array}$ \\
\hline
\end{tabular}

Note: ${ }^{\text {aAll }}$ regimens were QD.

Abbreviation: BP: blood pressure.

\section{References}

1. Weinberger MH, Roniker B, Krause SL, Weiss RJ. Eplerenone, a selective aldosterone blocker, in mild-to-moderate hypertension. Am J Hypertens. 2002;15:709-716.

2. White WB, Carr AA, Krause S, et al. Assessment of the novel selective aldosterone blocker eplerenone using ambulatory and clinical blood pressure in patients with systemic hypertension. Am J Cardiol. 2003;92:38-42.

3. Saruta T, Kageyama S, Ogihara T, et al. Efficacy and safety of the selective aldosterone blocker eplerenone in Japanese patients with hypertension: a randomized, double-blind, placebo-controlled, doseranging study. J Clin Hypertens. 2004;6(4):175-183.
4. Flack JM, Oparil S, Pratt H, et al. Efficacy and tolerability of eplerenone and losartan in hypertensive black and white patients. J Am Coll Cardiol. 2003;41:1148-1155.

5. Krum H, Nolly H, Workman D, He W, Roniker B, Krause S, Fakouhi $\mathrm{K}$. Efficacy of eplerenone added to renin-angiotensin blockade in hypertensive patients. Hypertension 2002;40(2):117-123.

6. Weinberger MH, White W, Ruilope LM, et al. Effects of eplerenone vs losartan in patients with low-renin hypertension. Am Heart $J$ 2005;150:426-433.

7. Williams GH, Burgess E, Kolloch RE, et al. Efficacy of eplerenone vs enalapril as monotherapy in systemic hypertension. Am J Cardiol 2004;93:990-996. 
8. White W, Duprez D, St-Hillaire R, et al. Effects of the selective aldosterone blocker eplerenone vs the calcium antagonist amlodipine in systolic hypertension. Hypertension 2003;41:1021-1026.

9. Parthasarathy HK, Menard J, White WB, et al. A double-blind, randomized study comparing the antihypertensive effect of eplerenone and spironolactone in patients with hypertension and evidence of primary aldosteronism. J Hypertens. 2011;29(5):980-990.

10. Pitt B, Reichek N, Willenbrock RW, et al. Effects of eplerenone, enalapril, and eplerenone/enalapril in patients with essential hypertension and left ventricular hypertrophy: the 4E-Left Ventricular Hypertrophy Study. Circulation. 2003;108:1831-1838.
11. Epstein M, Williams G, Weinberger M, et al. Selective aldosterone blockade with eplerenone reduces albuminuria in patients with type two diabetes. Clin J Am Soc Nephrol. 2006;1(5):940-951.

12. Burgess $\mathrm{E}$, Lacourcière $\mathrm{Y}$, Ruilope-Urioste $\mathrm{M}$, et al. Long-term safety and efficacy of the selective aldosterone blocker eplerenone in patients with essential hypertension. Clin Ther. 2003;25:2388-2404.

\section{Publish your work in this journal}

Vascular Health and Risk Management is an international, peerreviewed journal of therapeutics and risk management, focusing on concise rapid reporting of clinical studies on the processes involved in the maintenance of vascular health; the monitoring, prevention and treatment of vascular disease and its sequelae; and the involvement of metabolic disorders, particularly diabetes. This journal is indexed on PubMed Central and MedLine. The manuscript management system is completely online and includes a very quick and fair peer-review system, which is all easy to use. Visit http://www.dovepress.com/ testimonials.php to read real quotes from published authors. 